\title{
Perception Survey of Skill-Based Pay System and Employees Performance in Dormanlong Engineering Company Limited Port-Harcourt
}

\author{
Mba Okechukwu Agwu $^{1} \&$ Cletus Izunwanne Emeti ${ }^{1}$ \\ ${ }^{1}$ Faculty of Management Sciences, Business Administration, Niger Delta University, Wilberforce Island, \\ Bayelsa State, Nigeria \\ Correspondence: Mba Okechukwu Agwu, Faculty of Management Sciences, Business Administration, Niger \\ Delta University, Wilberforce Island, Bayelsa State, Nigeria. Tel: 234-803-793-6191. E-mail: \\ mbaagwu38@yahoo.com
}

Received: May 17, 2013

Accepted: July 10, 2013

Online Published: July 16, 2013

doi:10.5539/ijbm.v8n16p11

URL: http://dx.doi.org/10.5539/ijbm.v8n16p11

\begin{abstract}
The paper is a perception survey of skill-based pay system and employees' performance in Dorman long engineering company limited Port-Harcourt. The research question addressed the extent at which improved employees organizational commitment and broader role orientation is dependent on the implementation of skill-based pay system in Dorman long engineering company limited Port-Harcourt. It assumes that introduction of skill-based pay system affects the psychological contract of employees and their attitude towards the organization and their workroles. The core aspect of the study is the use of cross-sectional survey research design in generating the required primary data. The place of study is Dorman long engineering company limited Port-Harcourt while the duration of study is between May, 2012 and April, 2013. An exploratory cross-sectional survey research design was used in conducting the study using questionnaire administered on 348 randomly selected respondents from three categories of workers (50 supervisors, 150 foremen and 2,500workmen). The sample size of 348 was determined from a population of 2,700 employees using Yamane 1964 sample size determination formula at 5\% level of significance for sampling error. The questionnaire responses were presented using tables, analyzed and interpreted using simple percentages while formulated hypotheses were tested using chi-square $\left(\chi^{2}\right)$. The results indicated that improved employees commitment and broader role orientation are to a large extent dependent on the implementation of skill-based pay system. It therefore recommends among others: employees participation in the design and administration of SBP system, inculcation of group identification and cohesiveness in the skill-based work environment.
\end{abstract}

Keywords: skill-based pay system, employees' commitment, role orientation, self-efficacy, group identification

\section{Introduction}

Dorman long engineering company limited is a steel construction company located in Port-Harcourt, Nigeria. It has operational staff strength of 2,700 employees consisting of 50 supervisors, 150 foremen and 2,500 workmen. The company specializes in the construction of steel process vessels that are used in the oil and gas industry for chemical processing and storage. Since inception in 1998, the company has been using a job-based pay system in remunerating its workers until recently when it introduced a skill-based pay system to encourage employees to learn additional skills and be multi-functional in their approach to the job.

For employees to function effectively in a skill based pay (SBP) environment, they need to develop a broader role orientation for their jobs and increase their commitment to the organization. SBP has a great intuitive appeal to modern managers because it fits well with the post-bureaucratic organization era (Heckscher \& Donnellon, 1994). This new approach to employees'remuneration resulted in organizational structures becoming flatter, de-layered and flexible with fewer distinct job classifications and extensive use of cross-functional self-managed teams.

The idea of individuals holding specific jobs may no longer be appropriate and may need to be replaced with a more flexible view of organization based on the competencies and abilities of employees to achieve organizational goals. Skill-based pay system creates a multi-task workforce that provides greater flexibility in 
the assignment of tasks thus resulting in better problem solving capability, improved productivity/quality and reduced labour costs. This is because employees have the opportunity of becoming more familiar with the organization's total operations thus gaining a better understanding of their own contributions to the organization.

In a traditional job-based compensation system, the base pay that employees receive depends on the relative value of the jobs they hold in the organization. A major way to obtain an increase in base pay in such a system is to get promoted to a higher-valued job. In a skill based pay system, employees are paid according to the skills they possess. Skills are generally grouped into skill blocks, as an employee learns each block, his/her base pay goes up or increases. A skill block can include one or more of these skill sets: horizontal or breadth skillsfocuses on all related jobs in an integrated production process, depth skills- focuses on increased specialization in a particular area while vertical skills-focuses on professional and managerial jobs (Lawler, 1990).

SBP is practically more than a pay system because its application is accompanied by fundamental changes in the way work is designed/managed and a new perception of human resources and their role in the organization. It usually results in changing other components of employees total pay mix, especially benefits (Schuster \& Zingheim, 1992). The evidence available from survey based studies and case studies on SBP generally reports favourable effects on various outcomes: workforce flexibility as a result of multi-skilling, improved productivity, improved product quality, lower labour costs, increased employee motivation and increased organizational commitment (Jenkins, Ledford, Gupta, \& Doty, 1993). Among the main potential disadvantages associated with SBP is the increase in average wage rates.Unless increase in productivity outweighs the increase in average pay and training costs, higher overall labour costs will be the result. Lawler (1986) warned that it may be difficult to maintain the motivation of employees who become used to continuously learning higher skills and achieving higher pay after having learned all the available skill blocks in the SBP system.

A key feature of SBP is that it alters the nature of the relationship between employees and the employer and redefines the roles of employees so that they become cross-functional and able to undertake a broader set of tasks and responsibilities. It is against this background that it becomes pertinent to carry out a perception survey of skill-based pay system and employees' performance in Dorman long engineering company limited Port-Harcourt.

\subsection{Statement of the Problem}

The shift from traditional job-based pay to a skill-based pay system is usually induced by the firm's effort to adapt to uncontrollable changes in its environment or by the firm's effort to be proactive in adopting planned change processes in its systems and operations, so as to enhance its performance and effectiveness. Many experts in human resources recently have called for fundamental changes in reward systems. Proponents of such changes argue that existing reward systems "do not fit with the context and needs of the emerging downsized, de-layered, flexible, participative, dynamic, and diverse organizations" (Agarwal, 1997).

Changes in a firm's environment such as increased competition in product markets, changing technology, changes in a firm's external labour market as well as changes in the organization's structure and human resource management policies and practices can induce an organization to change from a job-based pay to a skill-based pay system. In most cases, SBP systems are used as part of a larger package in organizational change interventions, like the use of autonomous work teams, downsizing and organizational restructuring. The three major changes in today's business environment that are influencing organizations to change their structures and management systems include: globalized markets, technological changes and changes in the demographic composition of the population (Agarwal, 1997). Globalization of product, capital and labour markets put unprecedented pressures on organizations to improve their efficiency and competitiveness. Technological changes create a greater need for highly skilled employees who are able to keep their knowledge and competencies current. Changes in demographic composition of the workforce create a need to design suitable pay systems that reward effective performance.

Nowadays, most economies are knowledge-based, with the knowledge content of products and services' growing rapidly as information technology is increasingly becoming an integral partof products and services. By paying for individual knowledge and skills, organizations are hoping to empower employees and increase their development potentials. By increasing workers' skill levels and redirecting their attention, organizations gain increased workforce flexibility, decreased labour costs and increased productivity (Murray \& Gerhart, 1998). In the case of Dorman long engineering company limited Port-Harcourt, the implementation of SBP system was necessitated by the need to improve efficiency and remain competitive in the global steel construction industry. 


\subsection{Research Objectives}

Over the past few decades, organizations have been faced with continuing competitive pressures resulting from changing economic/social environments and workforce characteristics. These pressures are driving many organizations to transform their structures and seek more innovative management styles especially in remuneration administration. The objectives of this research are as follows:

1) To determine the extent at which improved employees organizational commitment is dependent on the implementation of skill-based pay system in Dorman long engineering company limited Port-Harcourt.

2) To determine the extent at which broader employees role orientation is dependent on the implementation of skill-based pay system in Dorman long engineering company limited Port-Harcourt.

\subsection{Research Questions}

The identified gap in employees' remuneration system created by changes in a firm's environment (increased competition, changes in technology and changes in the demographic composition of the workforce) necessitated a shift from the traditional job-based pay system to a skill-based pay system, thus prompting the following research questions:

1) To what extent is improved employees' organizational commitment dependent on the implementation of skill-based pay system in Dorman long engineering company limited Port-Harcourt?

2) To what extent is broader employees' role orientation dependent on the implementation of skill-based pay system in Dorman long engineering company limited Port-Harcourt?

\subsection{Research Hypotheses}

In view of the above research questions, the following null hypotheses were formulated:

$1 \mathrm{H}_{\mathbf{0}}$ : Improved employees' organizational commitment is not dependent on the implementation of skill-based pay system in Dorman long engineering company limited Port-Harcourt.

$2 \mathrm{H}_{\mathrm{O}}$ : Broader employees' role orientation is not dependent on the implementation of skill-based pay system in Dorman long engineering company limited Port-Harcourt.

\subsection{Literature Review}

The SBP system was pioneered by Procter and Gamble in the late 1960s and started to be applied increasingly by various organizations since then. However, the existing literature about SBP or competency-based pay is very limited and does not provide sufficient guidance regarding its impact on organizational and employee effectiveness. Most of the existing studies on SBP followed either case study or exploratory survey approaches that lack generalization and analytical rigor (Murray \& Gerhart, 1998). In order to understand the appropriate conditions for effective application of SBP and its outcomes, there is a need for studies that use rigorous research methods and theoretical models.

There is no SBP design that can work for every organization. Instead, the best design should be determined by a complete analysis of the work activities, organizational culture, and the available human, technical, and financial resources. A pay system in general should be tailored to fit the technical system and the social system in the organization (Ledford \& Bergel, 1991). This is particularly important when the pay system is relatively new and not commonly used as in the case of SBP. An important issue here is to analyze the existing organizational culture and the degree of readiness in accepting the change implied in adopting an SBP system. The lack of previous knowledge and experience of SBP system by both employees and managers entails careful planning in ensuring a smooth transition to the new pay system. It is very important to inform, involve and continuously communicate with employees, to ensure their understanding, acceptance and participation in the process of planning, designing and implementing the SBP system.

There are various methods that can be used to define the basic compensable factors in the SBP structure. Bunning (1992) identified six basic models for designing SBP structures ranging from the basic model, in which existing jobs are used as the basic 'skill blocks'- where an employee's pay is increased as he/she learns to perform additional jobs, to more complex designs in which a new job/work analysis for each work unit, is conducted and groups of skills are identified to represent the basic skill blocks in the pay structure. However, there is no reason to be limited to specific predefined models of SBP structures, different organizations may create different SBP structures depending on the organizational context, the nature of tasks performed and work complexity.

Generally, it is important that skill blocks are designed in a way that they can be measured reliably and also 
priced competitively. This task may not be easy to undertake because of possible lack of comparable pay surveys given that most available surveys are based on job-based pay structures. Also, the issue of measuring and pricing abstract managerial and professional skills/competencies is particularly complex and is still a subject of continuous debate (Hofrichter \& Spencer, 1996).

A key feature of SBP is that it alters the nature of the relationship between employees and the employer and redefines the roles of employees so that they become cross-functional and able to undertake a broader set of tasks and responsibilities. This implies a change in employees' perceptions in terms of their exchange agreement with their employer - a concept referred to as the "psychological contract" (Rousseau, 1995). The success of SBP system will be largely dependent on the organization's ability to design and manage the pay plan in a way that motivates employees to develop the desired attitudes and behaviours. It is important in this regard to examine the SBP system and how the changes it brings to the work environment affect employees' perceptions of their relationship with their employer and their work roles.

Understanding the determinants of employees' commitment and role orientation under SBP is very important because these attitudes will determine subsequent employee behaviours such as staying or leaving the organization and willingness (and ability) to perform the roles/activities expected in the SBP work environment. The more the training provided is directed towards firm-specific skills, the less, the possibilities of employees leaving their jobs after training. The human capital theory indicates that investments in the development of general skills are incurred by workers while firm-specific training is paid for by the firm (Becker, 1993).

It should be noted, however, that it may be difficult sometimes to distinguish between generic and firm-specific skills. As the complexity of the business environment increases, the line between the two types of skills blurs, especially with the heightened attention on generic competencies associated with work environments, characterized by empowered employees working in highly autonomous teams and independently making important decisions. The SBP system requires that employers not only pay for training on firm-specific skills, but also set the pay system to directly and automatically reward skill acquisition and application.

The SBP system is significantly different from the conventional job-based pay system, adopting it implies a major change in work relationships for employees and the way work is performed. A successful application of the SBP system requires treating it as a "planned change process" and preparing employees/management to adapt to the resulting change. One of the fairly established facts about SBP is that it works best with a participative, high involvement and non-bureaucratic work environment (Lawler, 1990).

A successful application of SBP, also, depends on the nature of workers, their potential for skill acquisition and their interest in acquiring more skills for higher future earnings. Employees with high levels of self-efficacy and consciousness are expected to perform well under the SBP system. Cable and Judge (1994) found that job seekers with high self-efficacy were more attracted to organizations that offer SBP than those with lower self-efficacy. According to Tannenbaum and Davis (1972) "people generally have much more to contribute and to develop than just what is expected of them in their specific positions. Whole persons, not parts of persons, are hired and available for contribution. The organizational challenge is to recognize this fact and discover ways to provide outlets for the rich, varied and often untapped resources available to them."

\subsection{Conceptual Framework}

The implementation of skill-based pay system in Dorman long engineering company limited Port-Harcourt is conceived from the perspective of the path model approach (AI-Wagfi, 2003), as shown in figure 1. It assumes that there are four characteristics of the SBP plan that shapes employee's attitude to the pay system: employees' understanding of the SBP plan involvement, employees' participation in the decision making process regarding the design and administration of the plan, training opportunities available and the certification/advancement procedures contained in the plan. These four characteristics in turn affects employees perception of the fairness and effectiveness of the SBP plan which dovetails on employees group identification and self-efficacy that ultimately influences employees level of organizational commitment and their role orientation in their respective jobs. 


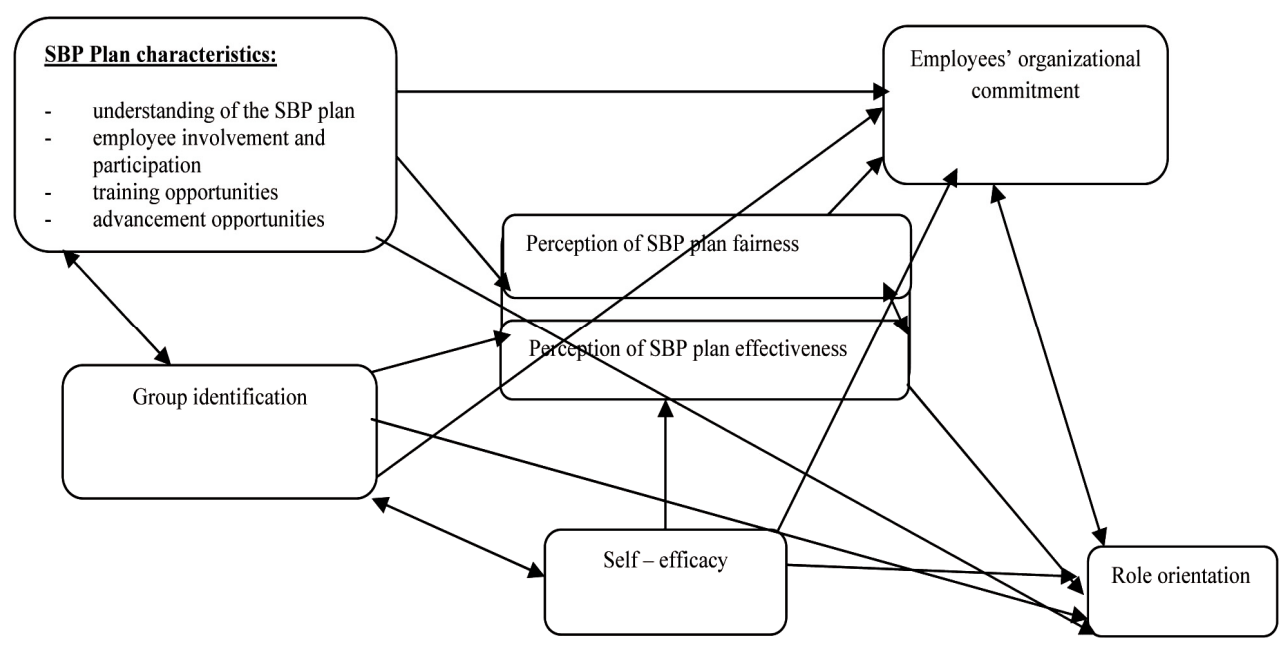

Figure 1. Determinants of employees' organizational commitment and role orientation in a skill-based pay system using apath model approach

Source: AI-Wagfi, M.A. (2003).The effects of a skill-based pay system on organizational commitment and role orientation .open access dissertations and theses. Digital commons@mcmaster. Paper 1437.

Role orientation refers to the psychological boundary of role (Parker et al, 1997). It includes the tasks, problems and competencies that an individual includes as part of his/her perceived work role. It also includes two other aspects: -production ownership- work goals and problems that the individual feels he/she is responsible for, and multi-skill recognition- employees' recognition of the importance of gaining and using a wide range of skills and knowledge for effective performance. Karakul and Theorell (1990) indication that narrow role orientation are derived from learned responses to early job experiences, in which taking initiative and using extra skill and judgment were severely penalized as overstepping the bounds of one's (unnecessarily restricted) authority. On the other hand, learning additional skills and multi-functioning are not only encouraged but also expected and required from employees under an SBP system.

We do not have sufficient empirical evidence or theoretical argument to suggest a specific direction of causality between organizational commitment and role orientation. It might be argued that the more committed employees are, the more they would be able to define their roles more broadly and assume greater responsibility and ownership of the work. On the other hand, one might argue that broader role orientation and high level of employees' involvement could lead to better understanding of the organization's business, its mission and goals. This may in turn, lead to higher level of organizational commitment. Therefore, we will not assume any causal effects between the two variables although it is believed that they correlate.

For an SBP plan to be perceived as fair, it must provide employees, the opportunity for involvement and participation in the design and administration of the plan. This will increase employees understanding and acceptance of the plan and its effectiveness. Some organizational commitment literature suggests that people's perception of their own competence (self-efficacy) might play a role in their effective commitment and effectiveness of the SBP plan. From an expectancy theory perspective, SBP plan can be expected to work best where employees are confident of their ability to learn and anticipate sufficient rewards to warrant the required investment of time and energy (Thompson and Lehew, 2000).

Tajfal (1978) suggests that group identification is part of an individual's self-concept which involves his/her knowledge of group membership and the value/emotional significance attached to that membership. The work environment where SBP is applied requires a high level of employee interaction and co-operation. Cross functioning and task rotation means that employees' will experience changing group dynamics and deeper interrelationships, with individuals and teams within their work environment. The quality of employees' relationship with fellow team members is reflected in their level of group identification. One would expect, therefore, that group identification will influence employees' perception of fairness and effectiveness of the SBP plan. Group identification is also expected to affect the quality of work life and employees' level of 
organizational commitment.

\subsection{Theoretical Framework}

The research is based on Vroom's (1964) expectancy theory and assumes that employees' beliefs about the effectiveness of the SBP plan will depend on how well the plan maximizes their effort - performance and performance - reward expectancies. To make an accurate assessment of these expectancies, employees need to understand clearly the pay system characteristics. A well designed SBP system is expected to produce higher employee motivation by enhancing both the expectancy and instrumentality of the skill acquisition and other work behaviors required to achieve the reward. A skill-based pay plan that clearly outlines the desired skills and reward attached to mastering and applying these skills, produce a highly motivated workforce, because it increases their effort-performance and performance-reward expectancies. This will increase employees' confidence in the ability of the pay system to effectively reward their efforts and contributions.

Also, employees' perceptions of the effectiveness and fairness of the SBP plan is expected to influence their attitude and behaviour towards organizational commitment and work role orientation. Effort-performance expectancy will be affected by employee characteristics such as ability to learn skills, self-efficacy and ability to fit into the work team. Expectancy theory also emphasizes the importance of outcome valence (desirability of skill acquisition and higher pay) as a motivator. This factor should be considered by management when deciding to apply an SBP plan on a group of employees. SBP plans should be designed in such a way that makes pay raises between different skill levels, high enough to motivate employees to continuously seek promotion and advancement in the pay structure through skill acquisition.

\section{Method}

The scope of the research is limited to the three categories of operational staff (supervisors, foremen and workmen) that are directly involved in steel construction activities in Dorman long engineering company limited Port-Harcourt. The core aspect of the study is the use of cross-sectional survey in generating the required primary data. The population of study consists of the entire 2,700 (50 supervisors, 150 foremen and 2,500 workmen) operational staff of Dorman long engineering company limited Port-Harcourt. A sample of 348 respondents determined at 5\% level of significance for sample error, using Yamane's 1964 formula, was selected using stratified random sampling method for the purpose of questionnaire administration.

The questionnaire was designed to obtain a fair representation of the opinions of the 348 sample respondents from the three categories of operational staff ( 7 supervisors, 19 foremen and 322 workmen) using a three-point Likert type scale. It is assumed that responses obtained from the sample respondents would be representative of the opinions of all the operational staff on their perception of skill-based pay system and employees' performance in Dorman long engineering company limited Port-Harcourt. The questionnaire responses of the sample respondents were presented using tables analyzed and interpreted using simple percentages while formulated hypotheses were tested using the chi-square $\left(\chi^{2}\right)$. A total of 348 copies of the questionnaire were administered, out of which 1 was cancelled, 2 were not returned while $345(99 \%)$ were used for the analysis.

\section{Results and Discussion}

\subsection{Distribution of Responses on Research Questions}

3.1.1 Question Number 1: To What Extent Does Your Company Implement Skill-Based Pay System in the Remuneration of Their Employees?

Table 1. Response pattern on the extent of implementation of skill-based pay system in Dorman long engineering company limited Port-Harcourt

\begin{tabular}{lcccc}
\hline Category of Respondents & \multicolumn{4}{c}{ Responses Provided } \\
\cline { 2 - 5 } & Large extent & Mild extent & Poor extent & Total \\
\hline Supervisors & 5 & 1 & 1 & 7 \\
Foremen & 12 & 5 & 2 & 19 \\
Workmen & 281 & 22 & 16 & 319 \\
Total & 298 & 28 & 19 & 345 \\
\hline
\end{tabular}

Source: Field Survey, 2013.

Table 1, indicates that a total of 298 i.e. $86.38 \%$ of the workers across the three categories, were of the opinion 
that their company to a large extent implements skill-based pay system in the remuneration of their employees, 28 i.e. $8.12 \%$ of the workers were of the view that their company to a mild extent implements skill-based pay system while 19 workers i.e. 5.51\% expressed a poor extent opinion. We therefore conclude that there is evidence of a large extent implementation of skill-based pay system in the remuneration of employees in Dorman long engineering company limited Port-Harcourtas buttressed by the $86.38 \%$ large extent response of the sample respondents.

3.1.2 Question Number 2: To What Extent Is Improved Employees' Organizational Commitment Dependent on the Implementation of Skill-Based Pay System in Your Company?

Table 2. Response pattern on the extent improved employees' organizational commitment is dependent on the implementation of skill-based pay system in Dorman long engineering company limited Port-Harcourt

\begin{tabular}{lcccc}
\hline Category of Respondents & \multicolumn{4}{c}{ Responses Provided } \\
\cline { 2 - 5 } & Large extent & Mild extent & Poor extent & Total \\
\hline Supervisors & 4 & 2 & 1 & 7 \\
Foremen & 9 & 6 & 4 & 19 \\
Workmen & 287 & 17 & 15 & 319 \\
Total & 300 & 25 & 20 & 345 \\
\hline
\end{tabular}

Source: Field Survey, 2013.

Table 2, shows that a total of 300 i.e. $86.96 \%$ of the entire respondents across the three categories of employees were of the opinion that improved employees' organizational commitment is to a large extent dependent on the implementation of skill-based pay system in their company. 25 i.e. $7.25 \%$ of the respondents were of a mild extent opinion while 20 i.e. $5.80 \%$ of the respondents were of a poor extent opinion. We therefore conclude that there is a strong evidence that improved employees' organizational commitment is dependent on the implementation of skill-based pay system in Dorman long engineering company limited Port-Harcourt as but tressed by the $86.96 \%$ large extent response of the sample respondents. This conclusion is supported by the survey study of Jenkins et al. (1993) which reported that 98 percent of their respondents indicated that their SBP plans were successful in increasing employees' commitment, level of job satisfaction and lower absent eeism/quit rates. Other studies also showed that SBP resulted in higher levels of commitment and lower turnover and absenteeism rates (Parent \& Webber, 1994).

3.1.3 Question Number 3: To What Extent Is Broader Employees' Role Orientation Dependent on the Implementation of Skill-Based Pay System in Your Company?

Table 3. Response pattern on the extent broader employees' role orientation is dependent on the implementation of SBP system in Dorman long engineering company limited Port-Harcourt

\begin{tabular}{lcccc}
\hline Category of Respondents & \multicolumn{4}{c}{ Responses Provided } \\
\cline { 2 - 5 } & Large extent & Mild extent & Poor extent & Total \\
\hline Supervisors & 4 & 2 & 1 & 7 \\
Foremen & 11 & 4 & 4 & 19 \\
Workmen & 275 & 29 & 15 & 319 \\
Total & 290 & 35 & 20 & 345 \\
\hline
\end{tabular}

Source: Field Survey, 2013.

Table 3, indicates that a total of 290 i.e. $84.06 \%$ of the entire respondents across the three categories of employees were of the opinion that broader employees' role orientation is to a large extent dependent on the implementation of skill-based pay system in their company. 35 i.e. $10.14 \%$ of the respondents were of a mild extent opinion while 20 i.e. $5.80 \%$ of the respondents were of a poor extent opinion. We therefore conclude that there is a strong evidence that broader employees' role orientation is dependent on the implementation of skill-based pay system in Dorman long engineering company limited Port-Harcourt as buttressed by the $84.06 \%$ large extent response of the sample respondents. This conclusion is supported by the survey study of (Tosi \& Tosi, 1986) in which 85 percent of their respondents indicated that, their SBP plans were successful in 
broadening employees'role orientation in organizational activities.

\subsection{Test of the First Hypothesis}

I. $\mathbf{H}_{\mathbf{O}}$ : Improved employees' organizational commitment is not dependent on the implementation of skill-based pay system in Dorman long engineering company limited Port-Harcourt.

II. $\mathbf{H}_{1}$ : Improved employees' organizational commitment is dependent on the implementation of skill-based pay system in Dorman long engineering company limited Port-Harcourt.

III. $\alpha=0.05$.

IV. Degree of Freedom $(\mathrm{df})=(\mathrm{r}-1)(\mathrm{c}-1=(3-1)(3-1)=4$.

V. Decision Rule: Reject Ho: if $\chi_{c}^{2}>\chi_{\mathrm{t}}^{2}$, Accept Ho: if $\chi_{\mathrm{c}}^{2}<\chi_{\mathrm{t}}^{2}$.

VI. Chi- square critical table value $\left(\chi_{\mathrm{t}}^{2}\right)=\chi_{0.05}^{2}=9.49$.

VII. Chi-square critical computed value $\left(\chi_{c}^{2}\right)$ from table $5=\chi_{c}^{2}=29.1966$

Table 4. Observed and expected frequencies of table 2

\begin{tabular}{lcccc}
\hline Category of Respondents & \multicolumn{4}{c}{ Responses Provided } \\
\cline { 2 - 5 } & Large extent & Mild extent & Poor extent & Total \\
\hline Supervisors & $4(6.09)$ & $2(0.51)$ & $1(0.41)$ & 7 \\
Foremen & $9(16.52)$ & $6(1.38)$ & $4(1.10)$ & 19 \\
Workmen & $287(277.39)$ & $17(23.12)$ & $15(18.49)$ & 319 \\
Total & 300 & 25 & 20 & 345 \\
\hline
\end{tabular}

Source: Field Survey, 2013.

Table 5. Computation of Chi-square critical computedvalue $\left(\chi_{c}^{2}\right)$ from table 4

\begin{tabular}{lllll}
\hline Fo & $\mathrm{Fe}$ & $(\mathrm{Fo}-\mathrm{Fe})$ & $(\mathrm{Fo}-\mathrm{Fe}) / \mathrm{Fe}$ & $(\mathrm{Fo}-\mathrm{Fe})^{2} / \mathrm{Fe}$ \\
\hline 4 & 6.09 & -2.09 & -0.3432 & 0.1178 \\
2 & 0.51 & 1.49 & 2.9216 & 8.5356 \\
1 & 0.41 & 0.59 & 1.4390 & 2.0708 \\
9 & 16.52 & -7.52 & -.4552 & 0.2072 \\
6 & 1.38 & 4.62 & 3.3478 & 11.2079 \\
4 & 1.10 & 2.9 & 2.6364 & 6.9504 \\
287 & 277.39 & 9.61 & 0.0346 & 0.0012 \\
17 & 23.12 & -6.12 & -0.2647 & 0.0701 \\
15 & 18.49 & -3.49 & -0.1888 & 0.0356 \\
\hline
\end{tabular}

Since $\chi_{c}^{2}>\chi_{t}^{2}$ i.e.29.1966>9.49, we reject the null hypothesis and accept the alternative hypothesis that improved employees' organizational commitment is dependent on the implementation of skill-based pay system in Dorman long engineering company limited Port-Harcourt as buttressed by the $86.96 \%$ large extent response of the sample respondents in Table 2.

\subsection{Test of the Second Hypothesis}

I. $\mathrm{H}_{\mathrm{O}}$ : Broader employees' role orientation is not dependent on the implementation of skill-based pay system in Dorman long engineering company limited Port-Harcourt.

II. $\mathrm{H}_{1}$ : Broader employees' role orientation is dependent on the implementation of skill-based pay system in Dorman long engineering company limited Port-Harcourt.

III. $\alpha=0.05$.

IV. Degree of Freedom $(\mathrm{df})=(\mathrm{r}-1)(\mathrm{c}-1=(3-1)(3-1)=4$.

V. Decision Rule: Reject Ho: if $\chi_{\mathrm{c}}^{2}>\chi_{\mathrm{t}}^{2}$, Accept Ho: if $\chi_{\mathrm{c}}^{2}<\chi_{\mathrm{t}}^{2}$.

VI. Chi- square critical table value $\chi_{\mathrm{t}}^{2}=\chi_{0.05}^{2}=9.49$.

VII. Chi-square critical computed value $\left(\chi^{2}\right)$ from table $7=\chi_{c}^{2}=13.7191$. 
Table 6. Observed and expected frequencies of table 3

\begin{tabular}{lcccc}
\hline Category of Respondents & \multicolumn{4}{c}{ Responses Provided } \\
\cline { 2 - 5 } & Large extent & Mild extent & Poor extent & Total \\
\hline Supervisors & $4(5.88)$ & $2(0.71)$ & $1(0.41)$ & 7 \\
Foremen & $11(15.97)$ & $4(1.93)$ & $4(1.10)$ & 19 \\
Workmen & $275(268.14)$ & $29(32.36)$ & $15(18.49)$ & 319 \\
Total & 290 & 35 & 20 & 345 \\
\hline
\end{tabular}

Source: Field Survey, 2013.

Table 7. Computation of Chi-square critical computedvalue $\left(\chi_{c}^{2}\right)$ from table 6

\begin{tabular}{lllll}
\hline Fo & $\mathrm{Fe}$ & $(\mathrm{Fo}-\mathrm{Fe})$ & $(\mathrm{Fo}-\mathrm{Fe}) / \mathrm{Fe}$ & $(\mathrm{Fo}-\mathrm{Fe})^{2} / \mathrm{Fe}$ \\
\hline 4 & 5.88 & -1.88 & -0.3197 & 0.1022 \\
2 & 0.71 & 1.29 & 1.8169 & 3.3011 \\
1 & 0.41 & 0.59 & 1.4390 & 2.0708 \\
11 & 15.97 & -4.97 & -0.3112 & 0.0969 \\
4 & 1.93 & 2.07 & 1.0725 & 1.1503 \\
4 & 1.10 & 2.9 & 2.6364 & 6.9504 \\
275 & 268.14 & 6.86 & 0.0256 & 0.0007 \\
29 & 32.36 & -3.36 & -0.1038 & 0.0108 \\
15 & 18.49 & -3.49 & -0.1888 & 0.0356 \\
\hline & & & & $\chi_{\mathrm{c}}^{2}=\mathbf{1 3 . 7 1 9 1}$ \\
\hline
\end{tabular}

Since $\chi_{c}^{2}>\chi_{t}^{2}$ i.e. 13.7191>9.49, we reject the null hypothesis and accept the alternative hypothesis that broader employees' role orientation is dependent on the implementation of skill-based pay system in Dorman long engineering company limited Port-Harcourt, as but tressed by the $84.06 \%$ large extent response of the sample respondents in Table 3.

The paper discussed skill-based pay system and employees' performance in Dorman long engineering company limited Port-Harcourt. The research question addressed the extent at which improved employees organizational commitment and broader role orientation is dependent on the implementation of skill-based pay system in Dorman long engineering company limited Port-Harcourt. It assumes that introduction of skill-based pay system affects the psychological lcontract of employees and their attitude towards the organization and their workroles. The three major findings of the research are as follows:

* Skill-based pay system is to a large extent implemented in remunerating employees in Dorman long engineering company limited Port-Harcourt.

* Improved employees organizational commitment is dependent on the implementation of skill-based pay system in Dorman long engineering company limited Port-Harcourt.

* Broader role orientation is dependent on the implementation of skill-based pay system in Dorman long engineering company limited Port-Harcourt.

Arising from the findings of this paper, it is suggested that the management of Dorman long engineering company limited Port-Harcourt should take the following measures to ensure success in the implementation of its skill-based pay system:

1) Involvement of employees in the design and administration of the SBP system will increase their understanding and acceptance of the plan and their belief in its effectiveness.

2) Encouragement of employees' group identification through interaction and co-operation to influence employee's perception of fairness and effectiveness of the SBP plan.

3) Determination of employees' compensation in accordance with the number, type and depth of skillsand abilities they possess to ensure that adequate attention is given to the trade-off between skill acquisition and production.

4) Re-engineering of the organizational structure (flat, de-layered, and flexiblestructures) to encourage the use of cross-functional self-managed teams to increase productivity and efficiency. 
5) Provision of training and skill acquisition resources to enable employees advance to higher skill levels.

6) Careful design of the SBP plan to suit the nature of the tasks at the work unit and the employees it covers to avoid discrepancies in its implementation.

7) Appropriate pricing of skills in a way that is consistent with conditions in the organization's labour market to reduce labour turnover to the barest minimum.

\section{Acknowledgements}

The authors are grateful to the management and staff of Dorman long engineering company limited Port-Harcourt especially those that completed and returned the research questionnaire and our wives/children for their moral support. Our sincere thanks go to the peer-reviewers for their painstaking efforts in going through the article and making necessary corrections.

\section{References}

Agarwal, N. C. (1997). Reward Systems: Emerging Trends and Issues. Canadian Psychology/Psychologie Canadienne, 39(1-2), 60-70.

AI-Wagfi, M. A. (2003). The effects of a skill-based pay system on organizational commitment and role orientation open access dissertations and theses, Paper 1437. Retrieved from http://digitalcommons.mcmaster.ca/opendissertations

Becker, G. S. (1993). Human Capital: A Theoretical and empirical Analysis with Special Reference to Education (3rd ed.). Chicago, IL: The University of Chicago Press. http://dx.doi.org/10.7208/chicago/9780226041223.001.0001

Bunning, R. L. (1992). Models for Skill-Based Pay Plans. HR Magazine, 12(2), 62-64.

Cable, D. M., \& Judge, T. A. (1994). Pay Preferences and Job Search Decisions: A Person-Organization Fit Perspective. Personnel Psychology, 47(4), 317-348. http://dx.doi.org/10.1111/j.1744-6570.1994.tb01727.x

Heckscher, C., \& Donnellon, A. (1994). The Post-Bureaucratic Organization: New Perspectives on Organizational Change. Thousand Oaks, CA: SagePublications.

Hofrichter, D. A., \& Spencer, L. M. (1996). Competencies: The Right Foundation for Effective Human Resource Management. Compensation andBenefits Review, 12(2), 20-26.

Jenkins, G. D., Ledford, G. B., Gupta, N., \& Doty, D. H. (1993). Skill-Based Pay: Practices, Payoffs, Pitfalls and Prescriptions. Phoenix, AZ: American Compensation Association.

Karasek, R., \& Theorell, T. (1990). Healthy Work: Stress, Productivity and the Reconstruction of Working Life. New York: Basic Books.

Lawler, E. E. (1986). High-Involvement Management. San Francisco: Jossey-Bass Publishers.

Lawler, E. E. (1990). Strategic Pay: Aligning Organizational Strategies and Pay Systems. San Francisco: Jossey-Bass Publishers.

Ledford, G. E., \& Bergel, G. (1991). Skill-Based Pay Case Number 1. General Mills Compensation and Benefits Review, 23(2), 24-56. http://dx.doi.org/10.1177/088636879102300205

Murray, B., \& Gerhart, B. (1998). An Empirical Analysis of A Skill-Based Pay Program and Plant Performance Outcomes. Academy of Management Journal, 4l(1), 68-78. http://dx.doi.org/10.2307/256898

Parent, K. J., \& Webber, C. L. (1994). Case Study: Does Paying for Knowledge Pay Off? Compensation and Benefits Review, 26(2), 44-50. http://dx.doi.org/10.1177/088636879402600509

Parker, S. K., Wall, T. D., \& Jackson, P. R. (1997). That is not my Job: Developing Employee Work Orientation. Academy of Management Journal, 40(4), 899-929. http://dx.doi.org/10.2307/256952

Rousseau, D. M. (1995). Psychological Contracts in Organizations: Understanding Written and Unwritten Agreements. Thousand Oaks, CA: Sage Publications.

Schuster, J. R., \& Zingheim, P. K. (1992). The New Pay. San Francisco: New Lexington Press.

Tajfal, H. (1978). Social Categorization, Social Identity and Social Comparison. In Tajfal, H. (Ed.), Differentiation between Social Groups: Studies in the Social Psychology of Intergroup Relations. London: Academic Press.

Tannenbaum, R., \& Davis, S. A. (1972). Values, Man, and Organizations. In Margulies, N., \& Raia, A. P. (Eds.), 
Organizational Development: Values, Process and Technology. New York: McGraw-Hill Book Company.

Thompson, J. R., \& LeHew, C. W. (2000). Skill-Based Pay as an Organizational Innovation. Review of Public Personnel Administration, 20(1), 20-40. http://dx.doi.org/10.1177/0734371X0002000103

Tosi, H., \& Tosi, L. (1986). What Managers Need to Know About Knowledge-Based Pay? Organizational Dynamics, 14(3), 52-64. http://dx.doi.org/10.1016/0090-2616(86)90031-8

Vroom, V. H. (1964). Work and Motivation. New York: John Wiley \& Sons Inc.

Yamane, T. (1964). Statistics: An Introduction Analysis (3rd ed.). New York: Harper and Row Publishers.

\section{Copyrights}

Copyright for this article is retained by the author(s), with first publication rights granted to the journal.

This is an open-access article distributed under the terms and conditions of the Creative Commons Attribution license (http://creativecommons.org/licenses/by/3.0/). 